\title{
Student's Perception of Library Services in Universities in Benue State.
}

\author{
Doosuur Ashaver, Mwuese D. Bem-Bura \\ Benue State University Library Makurdi
}

\begin{abstract}
The study examines how student perceive the library service offered in Benue state university and the federal university of agriculture Makurdi, Benue State. 200 students were randomly selected from these institutions for the purpose of the study. Questionnaire was used as main instrument for the gathering of data. The researcher also interviewed some of the librarians working in the libraries under study. The paper avers that most of the students were aware of library services as an indispensable tool for learning, teaching and research. The need to know how student perceive the library services offered to them by the librarians has been a concern for this study. It wonders whether the recent advancement in information and communication technology (ICT) and Bookstores has a negative effect on the use of library, or how the students perceive the library services offered to them. To this end, it sought to carryout research among the students of these universities in Benue that uses the library. The analysis underscores the perception of the students on those library services offered to them by their institution and how such services are been perceived by them and what needs to done in order to do away with their negative perception about the library.
\end{abstract}

\section{Back Ground of the Study}

\section{Introduction}

The university library is the bedrock upon which any university is built in order to achieve her primary aim of teaching learning, research and community service. University libraries are academic libraries established and attached to university are major aim of providing information material that supports teaching, learning and research.

University libraries are the depositories of knowledge that provide the vital under pinning for national development. Being integral part of the university, the libraries are of necessity, educational in purpose. The centrality of the university library is the intellectual life of the university community which is epitomized in the character and efficiency of the university which is gauged by its treatment of its central organ, the library. The university library is the principal instrument of the university in the conservation of recorded knowledge. Proper fulfilment of this role provides a sound basis for the transmission and advancement of knowledge.

However, every university library, no matter the size established to render services to its users. The library has to collect materials, published and unpublished, print and non-print, in some depth and globally in almost all the fields of knowledge not necessary in those offered in the university. However, the value of the records of human communication lies in the information they contain. Information can be stored in books, periodicals, Newspapers, teaching societies and professional associations, machine readable databases, manuscripts, archival materials and in many other formals. Although, the university libraries differ in size, population and in other respects, they serve the same purpose everywhere. Their function and objective are basically derived from their parent institution.

According to Aguolu and Aguolu (2002) the basic functions of any university is to conserve the existing knowledge, to transmit knowledge through teaching, and to create new knowledge through research. The university library is the university's principal instrument in the conservation of knowledge through its rational, systematic and comprehensive acquisition of all type of human communications records, publish and unpublished, written or oral in recorded form that embody the ideas of knowledge of past since each new idea or invention grows out of accumulated and conserved knowledge.

University libraries have the basic academic function of supporting teaching, learning and research activities that go on in their parent institutions. In performing this function university libraries stock thousands of information resource - both books, journals and other types of materials and provide access to them. However, the importance of well-stocked university libraries cannot be over- stressed; they contribute to the quality of the university as centres of learning and research. Thus the university library has been regarded as "the heart" of the unit - the most indispensable agency of unit for teaching and research .Nwalo (2002) summarised the basic materials needed in most institutional libraries, as:

- Reference books of a general nature and reference books in the subject areas including in the institutional programme. 
- Books which relates to and supplement each curriculum offered.

- Important general books not relating to a specific subject area and important books in subject field not included in the curriculum.

- Books for voluntary and recreational reading.

- Professional and research materials for both the faculty and certain student who requires them.

- Periodicals and Newspapers in foreign language, current issues, bound volume and those on microfilm, micro cards, and other microforms.

- Pamphlets and clippings.

- Audio-visual materials including picture films, slides, filmstrips, transparencies, music, photography, records, tape and wire recordings, maps and globes.

- Programmes materials.

- Government publications.

- Archival materials pertaining to the instruction.

- Equipment for the use of these materials such as micro-readers and listening and viewing equipment.

Any university community have major groups of primary users: undergraduates, graduate students, lectures and professors, and researchers from outside the university.

According to writtaker (1993) a user is a person who uses one or more of library's services at least once year. Hence, people who go to either the public or private libraries, seeking the attention of the library staff are known as the library users. This means that we have different categories of library users, as there are different types of libraries. In the course of this study, universities in Benue State will be researched on.

\section{Purpose of the study}

- $\quad$ To determine the library services offered to students in universities in Benue State.

- To investigate the adequacy of the library services offered to students in the universities in Benue State.

- To investigate the problem encountered by students in the provision of library services in universities in Benue State.

- $\quad$ To determine the strategies suitable for enhancing the library services offered to the university students in Benue State.

$\bullet$

\section{Scope of the study}

This study covers the perceptions of university students on library services in universities in Benue State, with emphasis on the hindrances to effective service delivery to students and how such services can be improved upon for the betterment of the students

\section{Significance of the study}

It is expected that the findings of this research will be of benefit to the following categories of people: students, librarians/library workers, library management and indeed, the university management. To students, librarians/library workers because, it will provide a guide to effective service delivery by librarians and library officer to users of the university libraries. To the university and library management because, it is expected that to cause them to make policies that will stimulate the workers to sit up to the challenges of effective service delivery such as on-the-job training for staff, in-service training, good monitoring strategies for staff, attendance and organization of workshops and seminars.

Also the findings of the research if implemented in libraries will unfold some of the lapses in effective service delivery thereby creating a positive change in the perception of students and attitude of librarians and library workers to service delivery.

Lastly, it is expected that the findings of this study will contribute to the existing literature in the field of the perception of students on library services in Benue state. It is also expected that it will enable future researchers to realise the need for further research and studies on the subject and guide them on various dimensions open for further research.

\section{Research Questions}

In order for the researcher to collect data on student's perceptions of library services in universities in Benue State, the following research questions were considered.

- What are the library services offered to students in universities in Benue State.

- How adequate are the library services offered to students in university in Benue State.

- What are the problems that hinder effective library services to students in universities in Benue State?

- What strategies can be adopted to ensure effective service delivery to student in universities in Benue State? 


\section{Population of the study}

The population of the study comprises of 9,300 students of university of Agriculture, Makurdi and 19,000 students of the Benue State University. The stratified random sampling technique was adopted in order to have samples proportional to the size of the institution for data collection; this was to avoid bias in the distribution of questionnaire to respondents. Because of the large number, the researcher used only $10 \%$ of the total number of respondents.

\section{Sample and Sampling Techniques}

The sample of the study consists of 200 students selected from the two universities. A stratified random sampling was used for each category of students.

\section{Instrument for Data Collection}

Data collections are questionnaire and interview. The instrument for data collection was divided into two sections. The first was to collect personal data of the respondent such as sex, age, institution and qualification.

The second section was meant to collect information for the research questions. It was a 4 item of questions grouped into 4 clusters. Each of the 4 clusters represents a research question. The respondents were required to tick the space in order to answer questions. While a structured interview, was also conducted.

\section{Method of Data Collection}

The questionnaire was distributed using the stratified random sampling among the students of both institutions. The administration of questionnaire and its collection after completion was done by the researcher herself, interviews were also conducted with some university library staff of both universities by the researcher respectively.

\section{Validation of Instrument}

The instrument was found to have face and content validity by experts in library and information science of the university of Nigeria Nsukka where the researcher is currently studying. They are Dr.E.O Omeje and Dr.V.N Nwachukwu, who scrutinized it and necessary corrections were made for the purpose of accurate data collection.

\section{Method of Data Analysis}

The simple percentage method was adopted for calculation of result. The result was presented in a tabular and the frequencies of respondent were used to calculate the percentage of item 1-3 and 4-7. The percentages were calculated using the formula of:

$$
N=\frac{X}{Y} \times \frac{100}{1}
$$

Where $\mathrm{N}=$ simple percentage

$\mathrm{X}=$ Number of responses

$$
\begin{aligned}
& \mathrm{Y}=\text { Total number of response } \\
& \frac{\text { Number of responses }}{\text { Total number of response }}
\end{aligned} \times \frac{100}{1}
$$

While the lickert method of, strongly agree, agree, strongly disagree, disagree great extent, fairly great extent, to some extent was used for calculating the mean result of item 4-7 respectively.

\section{Data Presentation And Analysis}

Logically the data collected was presented in tabular form and organised systematically in line with the research question and items in the questionnaires.

A total number of (200) copies of the questionnaire was distributed where each of the universities were given (100) copies each. However, only 169 copies were completed and returned from those institutions.

A. How do student perceive library services in universities in Benue State?

To be able to find out the perception of these students from the two universities on how they perceive those library services provided for them, the researcher posed the following questions.
a) What kind of library services is offered in your library?
b) How well do you benefit from these library services?
c) To what extent are these services made available? 
In answer to the above questions, table 1-3 have been analysis based on the responses from the respondents of both university.

Table 1: what kind of services are offered in your library?

\begin{tabular}{|l|l|l|l|l|l|}
\hline S/N & \multicolumn{1}{|c|}{ ITEM } & \multicolumn{4}{c|}{ RESPONSES } \\
\hline & & BSU & $\%$ & UAM & $\%$ \\
\hline 1 & ICT Services & 3 & 3.4 & 25 & 30.1 \\
\hline 2 & Reference services & 52 & 60.4 & 26 & 31.3 \\
\hline 3 & Library instructions & 10 & 11.6 & 13 & 15.6 \\
\hline 4 & Internet services & 16 & 18.6 & 11 & 13.2 \\
\hline 5 & Circulation services & 5 & 2.8 & 08 & 09.6 \\
\hline
\end{tabular}

That table above shows that 3 or $3.4 \%$ of responding and 25 or 30.1 of the respondents in Benue state university (BSU) and Federal university of Agriculture (FUAM) respectively agreed that ICT services are been offered in their libraries. 50 or $60.4 \%$ and or $31.3 \%$ agreed to the provision of reference services in their libraries. 10 or $11 \%$ and 13 or $15.6 \%$ agreed to library instruction been rendered in their libraries.160 or $18 \%$ and 11 or $13.2 \%$ agreed that circulation services are rendered in their libraries. While 5 or $5.8 \%$ and 08 or $09.6 \%$ agreed to internet services offered to students of this library.

Table 2: How well do you benefit from those services?

\begin{tabular}{|l|l|l|l|l|l|}
\hline S/N & Benefits Of Those Services & \multicolumn{4}{|c|}{ Responses } \\
\hline & & BSU & $\%$ & UAM & $\%$ \\
\hline 1 & Well & 40 & 46.5 & 50 & 60.2 \\
\hline 2 & Very well & 26 & 30.2 & 30 & 36.1 \\
\hline 3 & Not quite well & 20 & 23.2 & 03 & 03.6 \\
\hline
\end{tabular}

The above table shows that 40 to $46.5 \%$ respondents of BSU benefit well from those services provided by the library and 50 or $60.2 \%$ respondents of UAM respectively. 26 or $30.2 \%$ respondents of BSU benefit very well from those services provided by the BSU library and 30 or $36.1 \%$ respondents of UAM benefit very well from those services by their library. While 20 or $23.2 \%$ of respondents from BSU benefit and 03 or $03.6 \%$ of respondents from UAM benefit not quit well from those library services offered by the library to students.

Table 3: to what extent are those services made available to students of these universities under study?

\begin{tabular}{|l|l|l|l|l|l|}
\hline S/N & $\begin{array}{l}\text { Extent by which those services are made } \\
\text { available to students }\end{array}$ & \multicolumn{5}{|c|}{ Responses } \\
\hline & & BSU & $\%$ & UAM & $\%$ \\
\hline 1 & Very great extent & 41 & 47.7 & 45 & 54.2 \\
\hline 2 & Great extent & 30 & 34.9 & 32 & 35.6 \\
\hline 3 & Low extent & 15 & 17.4 & 06 & 07.2 \\
\hline
\end{tabular}

The table above shows that 41 or 47.7 and 45 or 54.2 of the BSU and UAM student have agreed that the extent to which library services are made available to them is to a very great extent. 30 to 34.9 and 32 or 35.6 of the BSU extent while 15 to 17.4 and 06 to 07.2 of the respective students agreed that such services are provided but to a low extent to students.

\section{Research Question 2}

How well do you benefit from the library services

1. How well do you benefit from the library resources?

2. How important are those library services offered?

3. How much has your personal library use changed since the introduction of internet services?

4. How well does the library resources help in your academic pursuit? 
Table 4: how well do you benefit from the library resources?

\begin{tabular}{|l|l|l|l|l|l|}
\hline S/N & Benefits of library services & Responses & UAM & $\%$ \\
\hline & & BSU & $\%$ & UAM & 40 \\
\hline 1 & Highly benefited & 50 & 58.1 & 48.2 \\
\hline 2 & Benefited & 30 & 34.9 & 38 & 45.8 \\
\hline 3 & Not benefit & 06 & 7.0 & 05 & 06.0 \\
\hline
\end{tabular}

The table above reveals that 50 to $58.1 \%$ and 40 to $48.2 \%$ of the respondents of BSU and UAM respectively agreed that they benefit highly from the library resources. 30 to 34.9 and 38 to 45.8 agreed that they benefit while 06 or $7.0 \%$ and 05 to $06.0 \%$ of the respondents said they do not benefit at all from library resources.

Table 5: How important are these library services offered in your library?

\begin{tabular}{|c|c|c|c|c|c|}
\hline $\mathbf{S} / \mathbf{N}$ & Importance of library services & \multicolumn{4}{|c|}{ Responses } \\
\hline & & BSU & $\%$ & UAM & $\%$ \\
\hline 1 & Very important & 40 & 46.5 & 45 & 54.4 \\
\hline 2 & Important & 30 & 34.9 & 25 & 30.1 \\
\hline 3 & Not very important & 10 & 11.6 & 09 & 11.0 \\
\hline 4 & Not important & 06 & 7.0 & 04 & 4.7 \\
\hline
\end{tabular}

Table 5 shows that 40 or $46.5 \%$ and 45 or $54.4 \%$ of the respondents in BSU and UAM respectively agreed that libraries still matter and are very important. 30 or $34.9 \%$ and 25 or $30.1 \%$ said the libraries are important, 10 or $11.6 \%$ and 09 or $11.0 \%$ said they are not very important while 06 or $7.0 \%$ and 04 or $4.7 \%$ of the respondents BSU and UAM said libraries are not important.

Table 6: how much has your personal library use changed since the introduction of internet services?

\begin{tabular}{|l|l|l|l|l|l|}
\hline S/N & $\begin{array}{l}\text { The level of library use since the } \\
\text { introduction of the internet in libraries }\end{array}$ & \multicolumn{2}{l|}{ Responses } \\
\hline & & BSU & $\%$ & UAM & $\%$ \\
\hline 1 & Increase & 51 & 59.3 & 42 & 50.3 \\
\hline 2 & Decrease & 29 & 33.7 & 38 & 45.7 \\
\hline 3 & Same & 06 & 7.0 & 03 & 4.0 \\
\hline
\end{tabular}

The table above shows that the level of library usage since the introduction of the internet in libraries has changed. This is supplied by the responses of 51 or $59.3 \%$ and 42 or $50.3 \%$ from BSU and UAM respectively. 29 or $33.7 \%$ and 38 or 45.7 said it decreases because of the introduction of internet facilities. While 06 or $7.0 \%$ and 03 or $4.0 \%$ said even though the introduction of the internet in libraries exist their usage still remain same.

Table 7: How relevant is the library resources in lien with your academic pursuit?

\begin{tabular}{|l|l|l|l|l|l|}
\hline & $\begin{array}{l}\text { The relevance of library resources in } \\
\text { academic pursuit }\end{array}$ & \multicolumn{3}{l|}{ Responses } \\
\hline & & BSU & $\%$ & UAM & $\%$ \\
\hline 1 & Very relevant & 45 & 52.3 & 49 & 59.0 \\
\hline 2 & Relevant & 29 & 33.7 & 25 & 30.1 \\
\hline 3 & Quit relevant & 30 & 11.6 & 8 & 01.2 \\
\hline 4 & Not relevant & 02 & 2.3 & 1 \\
\hline
\end{tabular}

Table 7 shows that 45 or $52.3 \%$ and 49 or $59.0 \%$ of the BSU and UAM student have agreed that the library resources provided for them are very relevant to their academic pursuit. 29 or 33.7 and 25 or 30.1 agreed that those resources are relevant to their academic pursuit. 30 or $11.6 \%$ and 8 or $01.2 \%$ of the respondent agreed to the resource been quit relevant to their academic pursuit while 02 or $2.3 \%$ and 1 or 01.2 of the respondents in BSU and UAM offers that such resources are not relevant to their academic pursuit and thinks to relay solely on their notebooks for their academic pursuit.

\section{Research Question 3:}

What are the problem hindering effective internet services in your library?

a) Which of the following problems do you encounter in getting the information needed?

b) What do you think is the factor responsible for this?

c) What do you think are the effect of these problems on the overall library services to students? 
Student's perception of library services in universities in Benue State.

Table 8: problem encountered in getting information from the library

\begin{tabular}{|c|c|c|c|c|c|c|c|c|c|c|c|c|c|}
\hline SN & \multicolumn{7}{|c|}{ Benue state university library } & \multicolumn{2}{|c|}{$\begin{array}{l}\text { Francis } \\
\text { FUAM }\end{array}$} & Sulem & \multicolumn{2}{|c|}{ Idachaba } & orary. \\
\hline & ITEM & SA & A & $\mathrm{D}$ & SD & $\mathrm{X}$ & REM & SA & A & $\mathrm{D}$ & SD & $\mathrm{X}$ & REM \\
\hline & $\begin{array}{l}\text { Lack of adequate } \\
\text { personnel }\end{array}$ & 25 & 16 & 19 & 26 & 2.46 & REJ & 20 & 19 & 27 & 15 & 2.48 & REJ \\
\hline 2 & $\begin{array}{l}\text { Limited resources in the } \\
\text { library }\end{array}$ & 15 & 10 & 8 & 53 & 1.484 & REJ & 25 & 38 & 10 & 10 & 2.93 & ACC \\
\hline 3 & Outdated library resource & 30 & 22 & 20 & 14 & 2.69 & ACC & 20 & 30 & 13 & 20 & 2.60 & ACC \\
\hline 4 & $\begin{array}{l}\text { Lack of interest on part of } \\
\text { students }\end{array}$ & 25 & 30 & 8 & 23 & 2.66 & ACC & 22 & 30 & 11 & 20 & 2.65 & $\mathrm{ACC}$ \\
\hline 5 & $\begin{array}{l}\text { Lack of effective } \\
\text { orientation to students }\end{array}$ & 20 & 18 & 22 & 16 & 2.37 & REJ & 10 & 28 & 20 & 25 & 2.27 & REJ \\
\hline 6 & $\begin{array}{l}\text { Lack of information } \\
\text { technical- know -how on } \\
\text { the part of staff to give } \\
\text { guidance/direction to } \\
\text { student }\end{array}$ & 50 & 10 & 20 & 6 & 3.20 & ACC & 40 & 20 & 10 & 10 & 3.08 & $\mathrm{ACC}$ \\
\hline
\end{tabular}

Table 8 shows that the lack of adequate personnel with the mean 2.46 of the Benue State University Library and the mean of 2.48 of the federal university of agriculture Library cannot be accepted to be cause of the problem encountered by student on getting information from the library. The table also reveals that the mean 1.84 of the BSUL concerning limited resources of the library has been rejected as a problem encountered by students of BSU on information retrieval. While 2.93 of FSIL of the University of Agriculture has been accepted that there is limited resources in their library which tends to be problem while seeking for information in the library. While outdated library resources is one of the problem encountered by students on getting information from the library. This can be proved by the mean of both university, while 2.69 is the mean of BSUL, 2.60 is that of UAM library. Another problem is on the part of the students whereby the students lack interest while in need of information, their seeking behaviour is not found, this is proved with the BSUL mean of 2.66 and UAM, 2.65 which is said to be problem on the part of students. While 2.37 of BSU and 2.27 of UAM mean has been rejected on the basis of lack of effective orientation to students from both institution as a problem encountered on information retrieval.

Finally, the lack of technical-know-how on the part of staff to direct students on information retrieval is found a problem with the mean of 3.20 and 3.08 of both institutions.

Table 9: factor responsible for ineffective retrieval of information in the library

\begin{tabular}{|l|l|l|l|l|l|l|l|l|l|l|l|l|l|l|}
\hline S/N & \multicolumn{9}{|c|}{ Benue state university library } & \multicolumn{3}{|l|}{ Francis } \\
FUAM
\end{tabular}

Table 9 shows that the factor responsible for ineffective retrieval of information in the BSUL is not as a result of limited number of staff in the library. This is represented by the mean $2.4 \%$ while that of FSIL shows that the limited number of staff is a factor responsible for the ineffective retrieval of staff is a factor represented by the mean 2.54. while 2.58 of BSUL and 2.75 of FSIL of UAM shows that the inadequate funds for New resources of the library is a factor responsible for ineffective retrieval of information of both library of the two institutions, as it is represented by the mean in the table above. It is of notice that another factor which is responsible for ineffective retrievals of information by students is abandon search in frustration which is caused by the students themselves. This is represented in the table by the mean 2.70 of BSUL and of FSIL. Lastly, the uncooperative attitude of staff of both university libraries is not a factor responsible for ineffective retrieval of information in 
Student's perception of library services in universities in Benue State.

the library as it is represented by the mean in the table above 2.29 of BSUL and 1.84 of FSIL of University of Agriculture Makurdi.

Table 10: Effects of the problems on the overall library services

\begin{tabular}{|c|c|c|c|c|c|c|c|c|c|c|c|c|c|}
\hline \multirow[t]{2}{*}{$\mathrm{S} / \mathrm{N}$} & \multicolumn{7}{|c|}{ Benue state university library } & \multicolumn{6}{|c|}{ Francis Suleman Idachaba library .F UAM } \\
\hline & ITEM & SA & A & $\mathrm{D}$ & SD & $\mathrm{X}$ & REM & SA & A & $\mathrm{D}$ & SD & $\mathrm{X}$ & REM \\
\hline 1 & Poor services & 30 & 26 & 20 & 10 & 2.88 & $\mathrm{ACC}$ & 20 & 41 & 12 & 10 & 2.88 & ACC \\
\hline 2 & $\begin{array}{l}\text { Low moral on the } \\
\text { part of staff }\end{array}$ & 15 & 30 & 20 & 21 & 2.45 & REJ & 22 & 31 & 10 & 20 & 2.66 & $\mathrm{ACC}$ \\
\hline & & & & & & & & & & & & & \\
\hline 3 & $\begin{array}{l}\text { Poor performance } \\
\text { and productivity }\end{array}$ & 14 & 12 & 40 & 20 & 2.23 & REJ & 30 & 20 & 22 & 11 & 2.83 & $\mathrm{ACC}$ \\
\hline 4 & $\begin{array}{l}\text { Lack of interest } \\
\text { on the use of } \\
\text { library }\end{array}$ & 22 & 14 & 20 & 30 & 2.32 & REJ & 33 & 10 & 35 & 5 & 2.85 & ACC \\
\hline
\end{tabular}

Table 10 above shows that all the items above : poor services with the mean of 2.88 , lack of interest on the use of library 2.32, low moral on the part of the staff 2.45 and poor performance and productivity 2.23 are the effect of the above problems of the overall library services performance in BSUL of Makurdi. While 2.85, as poor services, 1.66 as low moral on the part of staff, 2.83 as the poor performance and productivity and 2.85 as the lack of interest on the use of library among the students of FSIL library of university of Agriculture Makurdi shows that all the above mentioned are the effect of the problems on the overall library services to students.

\section{Research Question 4}

What measures can be taken to ensure the effective library services to students in University of Benue State.

Table 11: Strategies for enhancing library services to students

\begin{tabular}{|l|l|c|c|c|c|c|c|c|c|c|c|c|c|}
\hline S/N & \multicolumn{9}{|c|}{ Benue state university library } & \multicolumn{3}{|c|}{ Francis Suleman Idachaba library. F } \\
\hline & ITEM & SA & A & D & SD & X & REM & SA & A & D & SD & X & REM \\
\hline 1 & $\begin{array}{l}\text { Poor instruction to students } \\
\text { on the use of library }\end{array}$ & 50 & 30 & 5 & 1 & 3.50 & ACC & 40 & 33 & 9 & 1 & 3.34 & ACC \\
\hline & & & & & & & & & & & & & \\
\hline 2 & $\begin{array}{l}\text { More and proper } \\
\text { information dissemination } \\
\text { to uses }\end{array}$ & 49 & 27 & 6 & 4 & 3.40 & ACC & 52 & 11 & 8 & 2 & 3.12 & ACC \\
\hline & & & & & & & & & & & & & \\
\hline 3 & $\begin{array}{l}\text { New library resources } \\
\text { should be acquired for } \\
\text { effective library services }\end{array}$ & 52 & 22 & 10 & 2 & 3.44 & ACC & 46 & 31 & 3 & 3 & 3.44 & ACC \\
\hline & & & & & & & & & & & & & \\
\hline 4 & $\begin{array}{l}\text { Students should consider } \\
\text { the library inevitable }\end{array}$ & 24 & 30 & 22 & 10 & 2.79 & ACC & 30 & 22 & 2 & 10 & 2.86 & ACC \\
\hline & & & & & & & & & & & & & \\
\hline
\end{tabular}
the findings.

In regard to the above research question table 11 has been analyzed to show the responses or result of

Table 11 above shows that proper instruction to students on the use of library is necessary as a strategy for improving library services to students with the mean of 3.5 and that more and proper information dissemination to users should be necessary with a mean 3.40 and New library resources as another way of improving library services to students with the mean of 3.44 and finally, that students should change their negative perception about the library with the mean of 2.79 as a strategy for improving library services in Benue State University library. Whereas in FSIL proper instruction to students in the of library with the mean 3.34 and more proper information dissemination to students with the mean 3.12 and resources for the library should be acquired for effective service to students with the mean 3.44 and library with a mean of 2.86 if necessary for improving library services to students respectively.

\section{Conclusion}

Students in these universities have a negative perception on the library services rendered by these university libraries. This perception arise from lack of awareness by the students on how to search for 
information materials and ignorance on information search/retrieval strategies. Also carefully examined is the issue of outdated materials in the libraries. Students are frustrated when in search for current materials on a topic and cannot lay their hands on it easily, they resort to other means of information retrieval to the library which should serve them better and is free for all. Secondly, it was discovered that the attitude of most librarians and library officers toward students in search for information or awareness about library use and services is not encouraging. They should improve on their approach to library users and ensure that information delivery in each of libraries get to all users. Consequence upon the above, it is advised that the students of these universities take the course introduction to use of library, information communication and reading skills (GST221) very seriously while the university librarian embarks on annual library use orientation for new students.

\section{Recommendations}

For students to be able to see libraries and its supporting technologies as the life blood and arteries of the university and for the libraries to be able to serve the students better, every library administrators or information gate keepers must be aware of the relationship between the management of human resources, and the need to plan for more effective and efficient use of the staff through motivation, in-house, or on-the-job training and staff development. These are recognized techniques for improving individual performance and efficiency for successful and effective service delivery to students in university libraries.

In view of the immense significance of library materials, and the fact the users will always claim ignorance of the importance and existence of these provided materials, what is needed is not just provision of materials for students, but the librarians and library managers have a role to play in terms of creating awareness on availability and use of such materials.

Finally, the importance of libraries to function effectively in order to help the students survive in the rapidly changing academic environment of university education cannot be over emphasised. Therefore, student's perception should be used as a parameter to measure and evaluate current library services so as to improve on them where there is need.

\section{References}

[1]. Agbaanyi, A. (2007) Research and statistics for higher education, Makurdi: Destinyventures.

[2]. Aina, o. (2004) library and Information Science text for Africa. Ibadan: third world information service.

[3]. Attama, R. (2008) Polytechnic education library resources and technology Development of Nigeria. Global Review of Library and information science 1 (1) p. 18-20.

[4]. Bryson, J (2000) Effective Library and Information Centre management, $2^{\text {nd }}$ edition, Gower: Ashgate Publishing Ltd (169-17)

[5]. Cox, J. (2002) Information and Communication Technology; their role and value for science education New York: Open University Press.

[6]. Edoka, B.E. (2002) Introduction to Library Science, Onitsha: Palma Publishing and Link Company.

[7]. Ifidon, S.E. (1991) Essential of African University Library Management, Lagos: The National Library Press Ltd.

[8]. Ikegbune, E. (2003) The Use of the Library for College and University Students, Enugu: San Press.

[9]. Kenkins, C. (1991) Collection Management in Academic Libraries, Gower: Bookfied Ltd

[10]. Morgan, S. (1996) Developing Academic Library Skills for the future: Library Review 45.

[11]. Nwachukwu, C.C. (1998) Management: Theory and Practical, Onitsha: Africana -FEP Publishing Ltd.

[12]. Ode, E. and Omokaro, D. (2007) Basic Principal and Practice of Librarianship, Makurdi: PSG- Frank Publishing

[13]. Omekwu, C. (2003) The Challenges of Information System in Modern Libraries, Ibadan: Evi-Coleman Publication.

[14]. Otubelu, J. (2005) Introduction to Library Studies, Enugu: Lincel Publisher.

[15]. Sambe M. (2008) A Comparative Of Staff Training Programme in Benue State University Library Makurdi and Francis Sulemanu Idachaba Library of University of Agriculture Makurdi: Benue State. Unpublished MLS project, University of Nigeria, Nsukka.

[16]. Tooki, A. (2004) Integrating ICT into Nigeria Education: The Challenges ahead Financial Standard, October 25, P.L 